\title{
«On the Intertribal Conflict Known as 'The Takkalu Disaster' ». Meiji University Journal of Asian History, 10, 2005, pp. 55-67 [in Japanese].
}

\section{Akihiko Yamaguchi}

\section{(2) OpenEdition}

1 Journals

\section{Édition électronique}

URL : http://journals.openedition.org/abstractairanica/28452

DOI : 10.4000/abstractairanica.28452

ISSN : 1961-960X

Éditeur :

CNRS (UMR 7528 Mondes iraniens et indiens), Éditions de l'IFRI

\section{Édition imprimée}

Date de publication : 15 mai 2008

ISSN : 0240-8910

\section{Référence électronique}

Akihiko Yamaguchi, « « On the Intertribal Conflict Known as 'The Takkalu Disaster' ». Meiji University Journal of Asian History, 10, 2005, pp. 55-67 [in Japanese]. », Abstracta Iranica [En ligne], Volume 29 | 2008, document 189, mis en ligne le 15 septembre 2008, consulté le 26 septembre 2020. URL : http:// journals.openedition.org/abstractairanica/28452 ; DOI : https://doi.org/10.4000/abstractairanica. 28452

Ce document a été généré automatiquement le 26 septembre 2020.

Tous droits réservés 


\title{
«On the Intertribal Conflict Known as ‘The Takkalu Disaster' ». Meiji University Journal of Asian History, 10, 2005, pp. 55-67 [in Japanese].
}

\author{
Akihiko Yamaguchi
}

By analyzing the course of a civil war in 1531, generally known as "The Takkalu disaster," this paper reconsiders the process with which Šāh Țahmāsp, the second Safavid ruler, took power into his own hands. Since the ascendance of the young ruler, the reign of the Safavid State had remained in the hands of powerful Qizilbash leaders, who fiercely vied for the pre-eminent position of amir al-omarā. The incident began with the accession of Chūha Solțān Takkalu to this office in 1527. His lust for power caused a backlash against his tribe among other influential Qizilbash emirs, and this led to its elimination by the latter. The author, stressing that the Shah's labeling of the Takkalu tribe as possessed by the devil significantly affected the course of the event, concludes that the case should be regarded as a major turning point in the establishment phase of the Shah's process toward direct control over state affairs.

INDEX

Thèmes : 4.2.1. Safavides et Qâjârs 


\section{AUTEURS}

AKIHIKO YAMAGUCHI

University of Sacred Heart - Tokyo 